\title{
Effect on Value Earnings Management Company with Good Corporate Governance Practices as Moderating Variable
}

\author{
Emylia Yuniarti $^{1}{ }^{*}$, Mukhtaruddin ${ }^{1}$, and Nadia Hanim ${ }^{1}$ \\ ${ }^{1}$ Accounting Department Economic Faculty, Sriwijaya University, Palembang Indonesia
}

\begin{abstract}
Firm value reflects the size of the stock market reaction to the company. Increasing the value of the company is an achievement that suitable with the desire of the owner, because as the value of the company increasing as well the welfare of the owner. Earnings management has an influence on the value of the company. Good Corporate Governance to be one way to eliminate the management engineering efforts specifically to make regulations with the requirement for the companies to disclose certain information mandatorily and voluntarily. This research will discuss the influence of earnings management on company value, the effect of Corporate Governance on company value directly, and the effect of Corporate Governance as a moderating variable from the influence of earnings management and firm value. Data analysis technique used in this research is a descriptive data analysis method, analysis model and classical assumption check because this research aims to determine the effect of earnings management, company value and Corporate Governance on Enterprise State-owned Enterprises listed on the Indonesia Stock Exchange. The results of this study are earnings management negatively affect the value of the company, corporate governance itself has no effect on firm value, but as a moderating variable of corporate governance affect earnings management effect on firm value.
\end{abstract}

\section{Background}

The financial statements are the source of information for internal and external parties. Internal party here is the management company and its employees. Benefits own financial statements to internal parties is as information for making decisions, and as the evaluation of the financial information to the financial stability and profitability. Then external parties, namely investors, lenders, suppliers, customers and governments. The manager is one of the parties involved in the company's activities. As the parties involved in the activities of the company, managers have an obligation to provide information to external parties.

When the state sector in the management did not achieve the target profit, then management can modify the profit. One of the ways of management in the process of preparing financial statements that may affect the rate of profit is shown Profit Management is expected to enhance the Company's value at any given moment. Earnings

*Corresponding author: emylia_yuniarti@yahoo.com 
Management by management companies will increase the company's value (Tobin's Q) and then going down (Morck, Scheifer \& Vishny, 1988).

Corporate governance is one key element in improving economic efficiency, which includes a series of relationships between the company's management, board of directors, shareholders and other stakeholders. Corporate governance also provides a structure that facilitates the determination of the objectives of a company, and as a means to determine the performance monitoring techniques (Deni, Khomsiyah and Rika, 2004).

Based on research Herawaty (2008), earnings management has a significant effect on firm value. The asymmetry between the management and the owners provide opportunities for managers to manage earnings (Earnings Management) in order to increase the value of the company at a given time so as to mislead the owners (shareholders) of the company's true value. The increasing value of the company is an achievement, in accordance with the wishes of its owner, due to the increasing value of the company, the welfare of the owners will also increase. Value companies are also shareholder value reflects the size of the stock market reaction to the company. The greater the value of the company that shareholder value also reflects the public has assessed the stock market price over book value (Megawati, 2010).

Maximizing the value of the company is very important for a company, because to maximize value also means maximizing shareholder wealth that is the purpose of the company. The value of the company can deliver maximum shareholder wealth when the company's stock price to rise. The higher the stock price, the higher the wealth of shareholders. To achieve the company's value generally investors hand over its management to the professionals. The professionals are positioned as the manager or the commissioners.

In the process of achieving maximizes the value of the company will appear a conflict of interest between managers and shareholders in this case as the owner of the company (agency problem). Management of the company as the manager has more information about the company and the former more than the shareholders resulting asymmetry of information that enables management accounting practices oriented towards profit to achieve a certain performance

Based on what have described above, some question rise and will be analyse are: 1 . Is Profit Management positive effect on company value? 2. Does the practice of corporate governance positively affects firm value? 3. What is the effect of the Value Profit Management companies weakened by the practice of corporate governance proxy for Corporate Governance Perception Index?

\section{Literature Review}

In understanding the earnings management can be attributed to the agency theory as the theoretical rationale. Agency theory is the relationship between the agent and the principal manager here is that investors (Ujiyantho \& Bambang, 2007). Principal delegate responsibility for decision making to the agent, it can be said that the principal give a mandate to the agent to perform certain tasks in accordance with the employment contract has been agreed. Authority and responsibility as well as the principal agent stipulated in the employment contract by mutual consent (Muliati, 2011).

Earnings management is interference in external financial reporting process with the aim to benefit themselves. Earnings management is one of the factors that can reduce the credibility of financial statements, profit management add bias in the financial statements and may interfere with users of financial statements believe earnings figures as a result of engineering the earnings numbers without engineering (Setiawati \& Na'im, cited in Muliati 2011 ). Motivation of earnings management done for reasons of capital markets caused 
more by the general belief that the figures - accounting numbers, in particular profit is one of the important information that is used by investors to assess the price of shares Mulyono (2011), it is not surprising that there are some managers who seek to make their financial statements look good with the intent to influence the stock prices in the short term.

Corporate governance is a concept based on agency theory, is expected to serve as a tool to provide assurance to investors that they would receive a return on the funds they have invested. Corporate governance relates to how investors are confident that managers will benefit them, confident that the manager will not steal / darken or invest in projects that do not benefit related to the fund / capital already invested by the investor, and is concerned with how the investor control managers (Shleifer and Vishny, in Ujiyantho, 2007). In other words, corporate governance is expected to function to suppress or lower the cost of agency (agency cost). Corporate Governance assessment is currently able to use the data from the Indonesian Institute for Corporate Governance (IICG). Where the assessment CG using several assessment includes four stages: Self-assessment, collection Corporate Documents, Preparation of Papers and Presentations, and observations to the company.

One alternative used in assessing the value of the company is to use Tobin's Q. This ratio was developed by Professor James Tobin (1967). This ratio is a valuable concept because it shows the current estimate of the financial markets on the value of the return on every dollar of incremental investment. Company size is a variable that positively affect earnings management, which means that the larger the company measured by market capitalization, the greater the profit of the company management. This is because managers in large companies will receive incentives when they perform management in order to reduce post positive earnings. In addition, large companies should be able to meet the expectations of investors and many estimates and judgments that must be applied to large enterprises. Thus, the size of the company can be used as a consideration for potential investors to make investments and decisions.

\section{Research Framework}

This study aims to analyse the Influence of the Value Profit Management Company, the influence of corporate governance practices affect the value of the Company, Corporate practice Governance influence on the relationship between Earnings Management and Corporate Values.

\begin{tabular}{ll} 
Earning Management & Dependent Variable \\
\cline { 2 - 3 } Control Variable & Firm Size
\end{tabular}

Fig 1. Research Framework

The shareholders or owners of the company can only rely on reports from the company's management to know the state of his company. While managers as managers of the 
company to find out more information on the company's internal and prospects for the future, causing information gaps. This condition is often referred to as information asymmetry. Because of the asymmetry of information is the owner of the company cannot know the actual condition of the company so that the company's management has the opportunity to do a profit management. Basically, the manager earning management to enhance shareholder value. This activity can actually increase the value of the company at a certain period but can also reduce the value of the company in the future.

proposed hypothesis is:

$\mathrm{H} 1$ : Earnings management effect on firm value

In perspective, the agency theory, the risk adverse agent and which tend selfish will allocate resources (investing) which do not increase the value of the company. The agency issues would indicate that the value of the company will rise if the owners of ordinary companies controlling behaviour management in order not to waste resources companies, either in the form of investment that is not feasible, or in the form of shirking.

Corporate governance is a system that regulates and controls the company that is expected to provide and enhance the company's value to its shareholders. Thus, the implementation of good corporate governance is believed to increase the value of the company. Black et al. (2003) argued that first, the company will be better managed so that it can be more profitable higher dividends. Second, caused by outside investors can assess earnings or dividends equal to the higher of companies are implementing better corporate governance. The results showed that there was no evidence that companies with good corporate governance are more or pay higher dividends, but there is evidence that investors assess earnings or dividends equal to the current higher for firms with better corporate governance. the second hypothesis to be tested in this study is

$\mathrm{H} 2$ : Corporate governance effect on the company value

By reason of increasing the company value, management make a decision by doing earnings management. Therefore, the practice of corporate governance in the company will restrict Earnings Management for their mechanisms of control in the company. Corporate Governance Practices can be proxy by the CGPI.

Earnings management has a close connection with the company's internal conditions, as well as corporate governance. Therefore, in this research Good Corporate Government used as a moderation variable that strengthen the influence between earnings management and corporate value.

H3: Corporate Governance as a moderating variable effect on Earnings Management and Corporate Values

\section{Research Methodology}

Independent Variables

Independent variables in this study are earnings management. Earnings management here is the action of management to enhance shareholder value. According Rahmawati et al (2006) earnings management can be measured by discretionary accruals which calculated by subtracting the total accruals and accruals non-discreanitory.

Dependent Variables

The company value is the dependent variable, measured by Tobin's $Q$

$$
\mathrm{Q}=\frac{\mathrm{MVE}+\mathrm{D}}{\mathrm{BVE}+\mathrm{D}}
$$


Control Variables

Company size measured from the natural logarithm of the market value of the company's equity at the end, the number of shares outstanding at year end multiplied by the year-end stock market prices.

\section{Moderating Variable}

This variable was measured using an instrument that has been developed by the Indonesian Institute of Corporate Governance (IICG) in the form of Corporate Governance Perception Index (CGPI)

In this study, multiple regression model was used to test hypotheses of the study are:

1. $\mathrm{Q}_{\mathrm{it}}=\alpha_{0}+\alpha_{1} \mathrm{EM}_{\mathrm{it}}+\alpha_{2} \mathrm{UP}_{\mathrm{it}}$

2. $\mathrm{Q}_{\mathrm{it}}=\alpha_{0}+\alpha_{1} \mathrm{CGPI}+\alpha_{2} \mathrm{UP}_{\mathrm{it}}$

3. $\mathrm{Q}_{\mathrm{it}}=\alpha_{0}+\alpha_{1} \mathrm{EM}_{\mathrm{it}}+\alpha_{2} \mathrm{CGPI}+\alpha_{3} \mathrm{EM}^{*} \mathrm{CGPI}+\alpha_{4} \mathrm{UP}_{\mathrm{it}}$

$$
\begin{array}{ll}
\mathrm{EM} & =\text { Earnings Management proxy by Discretionary Accrual (DA) } \\
\mathrm{CGPI} & =\text { Corporate governance } \\
\mathrm{Q} & =\text { Tobin's Q proxy by Corporate Value } \\
\mathrm{UP} & =\text { Company Size proxy by the natural logarithm of the market value }
\end{array}
$$

\section{Empirical Result}

The test results showed that the first model variables Earnings Management, Company Size control variables which were statistically significant. Earnings Management adversely affect the Company Value Management means the use of earnings will decrease the value of the Company. Size may affect the company's earnings management where large enterprises have more complex operational activities allowing for an earnings management, but the company in the sample using the Earnings Management is not a strategy increases the Company Values.

Earnings management is done to raise the company value but in this study the earnings management is proven to reduce the value of the company. Distrust of others and investors against companies doing earnings management can decrease the value of the company itself. From the test results, the first hypothesis said that earnings management has a positive influence on the value of the company is not proved, because the earnings management negatively affect the value of the company. Increasing the possibility of earning management company, the smaller the value of the company.

In which regression model testing, CGPI negatively affect company value means the absence of CGPI effect on firm value indicating no consideration of such information by investors. Perhaps investors still do not trust the results of the survey appear CGPI especially the case of PT. Tin and Bank BNI which entered in the top 10 but the turmoil of performance the following year. Thus, IICG a great struggle to CGPI more credible and can be used as an indicator for investors in making investment decisions (Nuswandari, 2009). The test of the hypothesis 2 which says that corporate governance has a positive effect also not accepted because corporate governance has no effect on the value of the company directly. Corporate Governance corporate governance perception proxied using this index cannot affect the investor directly

The third regression model testing, variable Earning Management Company's positive effect on value. Variable CGPI has a negative effect on the Company Value means CGPI as moderating variables have a relationship. Seen from the value of the variable Management Earning third model to be smaller than the value of the variable Earning Management first model. 
Corporate Governance when used as moderating variables have an influence on the value of company this is because investors will consider the company's performance in terms of good corporate governance despite visible indications of earnings management in the company. Good corporate governance can reduce and prevent the occurrence of earnings management in the enterprise

\section{Conclusion}

Based on the analysis of research that has been done, it can be concluded that the sample of state-owned enterprises listed in the Indonesia Stock Exchange 2009 - 2013 are: Earning Management adversely affect the Company's value due to the effect of earnings management, it will cause the value of the company down. Variable corporate governance proxy for CGPI in this study had no effect on the Company Values. CGPI here considered cannot be considered outsiders to assess a company. Variable corporate governance is moderating variables between Earnings Management and Corporate Values. Indirectly Corporate Governance variables affecting earnings management influence on corporate value, where the value of the company is getting better with the influence of this CGPI. The size of the company affect the company value in each regression models were conducted. This means that the larger the company the greater the Corporate Value.

\section{References}

1. G. Boediono, "Kualitas Laba: Studi Pengaruh Mekanisme Corporate Governance dan Dampak Manajemen Laba Dengan Menggunakan Analisis Jalur". SNA VIII (2005)

2. D. DarmawatI, Khomsiyah dan Rika Gelar Rahayu. 2004. "Hubungan Corporate Governance dan Kinerja Perusahaan”. SNA VIII (2004)

3. I. Ghazali, Aplikasi Analisis Multivariate SPSS. Semarang: BP UnDip. (2005)

4. V. Herawaty, "Peran Praktek Corporate Governance Sebagai Variabel Moderating dari Pengaruh Earnings Management Terhadap Nilai Perusahaan”. SNA XI (2008)

5. Megawati. "Pengaruh Corporate Governance, Leverage, dan Manajemen Laba Terhadap Nilai Perusahaan yang Termasuk Kelompok Jakarta Islamic Index tahun 2005-2007”. UIN Sunan Kalijaga, Yog (2010) http://digilib.uinsuka.ac.id/3489/1/BAB\%20I\%2CV.pdf

6. NK. Muliati, "Pengaruh Asimetri Informasi dan Ukuran Perusahaan pada Praktik Manajemen Laba di Perusahaan Perbankan yang Terdaftar di Bursa Efek Indonesia". Universitas Udayana, Denpasar (2011)

7. http://www.pps.unud.ac.id/thesis/pdf thesis/unud-780-tesisktmuliati.pdf

8. D. Mulyono, Dwi, "Pengaruh Manajemen Laba (Earning Manajement) Terhadap Kinerja Keuangan". Tesis. Universitas Islam Indonesia Malang. (2011) dari http://lib.uin-malang.ac.id/?mod=th detail\&id=08510022

9. Morck, R. And A. Shleifer, and R.W. Vishny, Management Ownership and Market Valuation: An Empirical Analysis. J of Fin Ec, 20, 293-315, (1988)

10. Sunarto. 2009. “Teori Keagenen dan Manajemen Laba”. Kajian Akuntansi, Vol. 1 No. 1. ISSN : $1979-4886$

11. SWA 27/2009, 21 Desember 2009

12. SWA $26 / 2010,9$ December 2010

13. SWA $27 / 2011,21$ December 2011

14. SWA 27/2012, 21 December 2012

15. SWA 27/2013, 23 December 2013 
16. M. Arief Ujiyantho, dan Bambang Agus P. "Mekanisme Corporate Governance, Manajemen Laba dan Kinerja Keuangan”, SNA X Makassar, (2007)

17. T.A. Utama, dan Abdul Rohman. "Pengaruh Corporate Governance Perception Index, Profitabilitas, Leverage, dan ukuran Perusahaan Terhadap Nilai Saham". Dip.. J. of Acc.. 2 No. 2, (2013), 1-9 